УДК 94 (477.7) : 902.2

DOI: https://doi.org/10.33782/eminak2021.1(33).498

\title{
ВАРВАРСЬКІ ЛИВАРНИКИ У НИЖНЬОМУ ПОБУЖЖІ В АРХАЇЧНИЙ ЧАС
}

\author{
Сергій Ольговський \\ Київський національний університет культури і мистецтв (Київ, Україна) \\ e-mail: olgovskiy@online.ua \\ ORCID: https://orcid.org/0000-0002-8677-9312
}

\begin{abstract}
У статті аналізується рівень розвитку бронзоливарного ремесла у Північному Причорномор'ї у VI-V cm. до н.е. Автор дійшов висновку, що всупереч традиційній думці про виняткову роль античних колоній в історії місцевого населення, кольорова металообробка у грецьких колоніях поступалася скіфській за обсягом і складністю технологічних прийомів. Така точка зору сформувалася у результаті певної лакуни у дослідженні скіфських пам'яток осілого побуту, яка трималася до 50-х рр. ХХ ст., коли розпочалися широкі дослідження скіфських городищ лісостепової зони. Практично на кожному великому городищі виявлено яскраві сліди місцевої металообробки, які за кількістю й якістю значно перебільшують ольвійські. Аналіз решток металообробного ремесла в Ольвії й у Нижньому Побужжі в цілому дає можливість стверджувати, що у зазначений час в Ольвії $і$ на поселеннях ї̈ хори, на Березанському й Ягорлицькому поселеннях здебільшого працювали бродячі майстри - вихідці із варварського середовища - Балкано-Карпатського басейну, лісостепової зони Украӥни, Північного Кавказу і, навіть, Волго-Уралля та Західного Сибіру.
\end{abstract}

Ключові слова: кольорова металообробка, бронзоливарне ремесло, бродячі майстри, ливарні форми

Актуальність дослідження полягає у необхідності переоцінки ролі античних колоній у житті місцевого населення Північного Причорномор'я, яке традиційно розглядалося як споживач досягнень грецької культури. Вивчення рівня розвитку кольорової металообробки у Подніпров'ї в VI-V ст. до н.е. дає можливість поновому подивитись на перебіг подій і по-іншому розставити акценти.

Мета дослідження полягає у порівняльному аналізі матеріалів, що стосуються кольорової металообробки у Нижньому Побужжі та Середньому Подніпров'ї і визначенні ролі місцевих ливарників у розвитку цього ремесла в архаїчний час.

Традиційно співвідношення ливарництва у регіоні оцінювалося на користь грецьких колоній, насамперед Ольвії, ливарники якої начебто із самого початку існування міста налагодили виробництво речей у варварському стилі для забезпечення ними місцевого населення. При цьому не враховувалися результати досліджень скіфських пам'яток осілого побуту за останні десятиліття і деякі морфологічні характеристики артефактів, пов'язаних із ольвійським бронзоливарним ремеслом, що дозволяло б зробити переоцінку пріоритетів на користь скіфських ремісників. Щодо скіфських ремісничих центрів ми вже відзначали, що, у порівнянні 3 античними колоніями, вони почали значно пізніше досліджуватись і думка, яка склалася до 50-х рр. ХХ ст., продовжувала превалювати, незважаючи на активну публікацію матеріалів розкопок ${ }^{1}$.

1 Ольговський С.Я Скіфо-антична металообробка архаїчного часу. Київ: КНТ, Университет Д. Пожарского, 2011. С. 4. 
Наприклад, у розділі, присвяченому бронзоливарному ремеслу скіфів, в академічному виданні «Археология Украинской ССР» було відзначено, що майстерень, де оброблялись кольорові метали, в Скіфії не виявлено (виділено автором). На поселеннях зустрічаються тільки незначні (виділено автором) сліди металообробки: ллячки, тиглі, зливки і краплі міді, браковані вироби, ливарні форми. Техніка обробки металів вивчається тільки за готовими виробами. Все металообробне ремесло концентрувалося в античних містах Північного Причорномор'я².

Зауважимо, що такі «незначні» сліди відкривали широкі перспективи у дослідженні місцевої металообробки, тим більше, що у 1986 р., коли виходило з друку вже друге видання «Археологии УССР», де було наведено дану оцінку скіфського ремесла, вже були відомі й опубліковані у науковій літературі матеріали із бронзоливарних майстерень на Більському городищі, виявлені у 1965 р. ${ }^{3}$ й у 1969 р. 4 У другій з них, окрім плавильної печі й традиційного супроводжуючого майстерні матеріалу у вигляді відходів виробництва, було виявлено уламки ливарної форми, в якій відливалися масивні щитові умбони у вигляді лежачого оленя, аналогічного відомій блясі із кургану кінця VII - початку VI ст. до н.е., дослідженого біля станиці Костромська на Кубані, яка до цього традиційно вважалася продукцією грецьких колоніальних майстрів.

На правому березі Дніпра виразні сліди бронзоливарного ремесла VI-V ст. до н.е. у вигляді решток плавильних печей, інструментів, ливарного бруду, шлаків, напівфабрикатів, тиглів та ін. виявлені на городищах: Жаботинському у пониззі р. Тясмин, Шарпівському і Мотронинському, та на поселенні Грищенці поблизу Канева. Сліди діяльності заїжджих майстрів було виявлено також на Трахтемирівському городищі.

На лівому березі Дніпра потужними ремісничими центрами були городища Більське, Коломакське, Полкова Микитівка, Люботинське, Лихачівське, Книшівське. Відомі також невеликі селища, на яких зафіксовані рештки бронзоливарного ремесла, наприклад, три селища поблизу Коломакського городища, які, ймовірно, i знаходились у сфері впливу коломакських майстерень, виконуючи, можливо, роль його філій, а також біля станції Шовкова.

Відомі у лісостеповому Правобережжі і випадкові знахідки ливарних форм, не пов'язані із конкретними ремісничими центрами, або із рядовими землеробськими поселеннями․ Останнім часом таких знахідок стало значно більше, але знаходяться вони у приватних колекціях й отримати інформацію про умови їх виявлення не завжди вдається.

У Нижньому Побужжі майстерні відомі тільки в Ольвії, але в жодній з них не виявлено ніяких спеціалізованих інструментів або ливарних форм. Всі ливарні рештки були знайдені окремо, або ж у сміттєвих ямах, в які тривалий час скидали шлаки, стінки від печей тощо. На Березанському поселенні відомі лише декілька лива-

\footnotetext{
2 Ильинская В.А., Тереножкин А.И. Материальная культура. Занятия и орудия труда // Археология Украинской ССР. Киев: Наук. думка, 1986. Т. 2. С. 131-132.

3 Шрамко Б.А. Исследования лесостепной полосы УССР // Археологические открытия 1966 г. Москва: Наука, 1967. С. 199-201.

4 Шрамко Б.А. Новые находки на Бельском городище и некоторые вопросы формирования и семантики образов звериного стиля // Скифо-сибирский звериный стиль в искусстве народов Евразии. Москва: Наука, 1976. С. 195-196.

5 Штітельман Ф. Дві ливарні форми для бронзових наконечників стріл із збірки Київського історичного музею // Археологія. 1947. Т. І. С. 16.
} 
рних форм для виготовлення дрібних прикрас, напівфабрикати наконечників стріл, бронзові шлаки, але всі вони знайдені самі по собі і не пов'язані навіть із житловими землянками ${ }^{6}$. На Ягорлицькому поселенні також майстерні не виявлені. Але зібрано багатий матеріал, який свідчить, що ливарництво тут займало далеко не останнє місце - це чисельні шлаки й уламки тиглів, зливки бронзи та свинцю, напівфабрикати наконечників стріл і прикрас, готові вироби. При цьому слід відзначити надзвичайно широкий типологічний діапазон цих виробів. Бронзові прикраси, наприклад, знаходять собі яскраві аналогії на Північному Кавказі, у Балкано-Карпатському басейні, лісостеповому Подніпров'ї і, навіть, далеко на сході.

Найімовірніше, що у Нижньому Побужжі спочатку працювали варварські майстри - вихідці із різних регіонів - Балкан, Подніпров'я, Волго-Уралля, Північного Кавказу. Якщо на Березанському та Ягорлицькому поселеннях вони затримувалися ненадовго, то в Ольвії можна було орендувати приміщення на тривалий час й облаштовувати у них майстерні.

На декількох поселеннях ольвійської хори також було знайдено, на перший погляд, переконливі сліди обробки кольорових металів. Це поодинокі уламки ливарних форм, уламки тигелів з рештками свинцю, шматочки мідного шлаку. Ніяких слідів стаціонарних майстерень, або ділянок культурного шару зі слідами виробничої діяльності, немає і всі ці знахідки одразу звертають на себе увагу, оскільки вони виділяються на загальному фоні звичайних для сільськогосподарських поселень знахідок. Крім того, форми, виявлені на поселеннях хори, спрацьовані, тобто були тривалий час у використанні, і не придатні для подальшого використання, а наявність уламків тиглів із рештками металу та мідні шлаки свідчать про те, що тут здійснювалося лиття мідних сплавів.

Так на поселенні Козирка 15 було виявлено стулку ливарної форми для відливання свинцевих пряслиць ${ }^{7}$. Уламки сильно зношених стулок для відливання таких же виробів були знайдені на поселеннях Стара Богданівка8 і Козирка 99. На поселенні Чортовате 7 було знайдено стулку форми для відливання ворварок, а з поселення Велика Чорноморка походить уламок тигеля, в якому плавили свинець 10. На поселенні Петухівка зафіксовані мідні шлаки ${ }^{11}$. Ніяких інших слідів обробки металів на цих поселеннях не виявлено, однак картографування цих знахідок дало можливість А.С. Островерхову та В.М. Отрешку стверджувати, що навколо такого, як вони вважають, потужного металообробного центру, яким була Ольвія, цілком закономірна організація мережі дрібних бронзоливарних майстерень ${ }^{12}$.

Але, враховуючи недоцільність організації таких майстерень на невеликих сезонних поселеннях, якими, на думку В.М. Отрешка, була більшість із них, про що

\footnotetext{
6 Ильинская В.А., Тереножкин А.И. Материальная культура... С. 67.

7 Рубан В.В. Литейная форма с поселения Козырка XV // Советская археология. 1979. № 3. С. 249.

8 Марченко К.К., Доманский Я.В. Комплекс вещественных находок на античном поселении Старая Богдановка 2. // Археологический сборник Государственного Эрмитажа. Вып. 24. 1983. С. 71-72.

9 Крыжицкий С.Д., Буйских С.Б., Бураков А.В., Отрешко В.М. Сельская округа Ольвии. Киев, 1989. C. 79.

10 Гаврилюк Н.А., Отрешко В.М. Лепная керамика архаического поселения Большая Черноморка 2 // Древности Степной Скифии. Киев, 1982. С. 86.

11 Славин Л.М. Основные итоги исследования Ольвии за последние годы // VI Научная конференция ИА АН УССР: сб. ст. Киев, 1953. С. 136.

12 Островерхов А.С., Отрешко В.М. Новый образец звериного стиля, найденный близ Ольвии // Памятники древнего искусства Северо-Западного Причерноморья. Киев, 1986. С. 64.
} 
йшлося вище, єдине пояснення, яке можна знайти перерахованим знахідкам, - це робота ливарників на виїзді, у майстернях тимчасових, можливо, відкритого типу або переносних. Відливались у формах речі утилітарного призначення, в яких була потреба у мешканців поселень, але і обійтись без них вони теж могли, принаймні у розпалі сезону в Ольвію за ними вони б не поїхали. Інша справа, коли ці речі їм пропонують на місці. У цьому і полягає специфіка роботи на виїзді: виявлення потреб населення та задоволення попиту на місці, оскільки весь необхідний інструмент у таких майстрів був із собою. Можливо, що плавильні печі також були переносні або їх робили тимчасовими, поза приміщеннями.

Враховуючи ж відсутність решток стаціонарних майстерень або яких-небудь інструментів ремісників, що свідчить про недовге перебування майстрів на цих поселеннях, стає зрозумілим, що працювали тут мандрівні майстри. Для виготовлення свинцевих виробів не потрібна майстерня, свинець можна було розплавити і на вогнищі, але те, що речі відливались у ливарних формах, виготовлених із урахуванням всіх тонкощів, без примітивізму, свідчить, що працювали тут професіонали. Можливо база цих майстрів знаходилася в Ольвії і цілком закономірно, що вони знали географію хори та потреби її мешканців.

Ще одна знахідка зазвичай фігурує при характеристиці ольвійського бронзоливарного ремесла, або ремесла на ольвійській периферії. Це двостулкова кам'яна ливарна формочка із поховання, дослідженого М. Ебертом у 1910 р. у Марицинському могильнику, в урочищі Аджигол неподалік від Ольвії13. У цій формочці повинні були відливатись бляшки у вигляді голівки кошачого хижака - пантери, або барса. Аналогічну бляшку-позитив було виявлено на поселенні Широка Балка, розташоване у 3 км на південь від Ольвії14, що ще більше посилювало значущість марицинської знахідки й Ольвія вважалася чи не єдиним центром виготовлення подібних бляшок, звідкіля вони розповсюджувались серед кочовиків у Скіфії.

Справа в тому, що супроводження поховання аксесуарами ремесла, зокрема ливарними формами, - явище досить рідкісне і притаманне, в основному, періоду ранньої та, частково, середньої бронзи. Є.М. Черних, наприклад, для цього часу виділяє близько десяти поховань з речами, які мають безпосереднє відношення до бронзоливарного ремесла15. Однак цю думку було висловлено ще у середині 70х pp. XX ст., а на початок 1990-х рр. тільки для катакомбної культури приазовськочорноморської зони було картографовано близько сорока поховань, супроводжених ковальськими й ливарними аксесуарами - формами, тиглями, соплами, кам'яними наковальнями тощо ${ }^{16}$. Ніякого зв'язку цих поховань 3 конкретними майстернями, або просто поселеннями чи стоянками цього часу, не відзначено.

У майбутньому лише у VI-VII ст. вже нової ери з'являються поховання із тиглями, ллячками та ливарними формами, але далеко за межами території, що розглядається. Це Поволжя та землі фіно-угорських племен ${ }^{17}$. Тобто марицинську знахід-

\footnotetext{
${ }_{13}$ Ebert M. Ausgrabungen auf dem Gute Maritzyn, Gouw Cherson // PZ. Leipzig, 1913. Bd. V. H. 1-2. S. 9, fig. 6.

14 Яценко И.В. Скифия VII-V вв. до н.э // Труды Государственного исторического музея. Вып. 36. Москва, 1959. С. 29.

15 Черных Е.Н. Древняя металлообработка на Юго-Западе СССР. Москва, 1976. С. 166.

16 Кубышев А.И., Нечитайло А.Л. ЦЦентры металлообрабатывающего производства АзовоЧерноморской зоны (к постановке проблемы) // Катакомбные культуры Северного Причерноморья. Киев, 1991. С. 6.

17 Голубева Л.А. Девочки-литейщицы // Древности славян и Руси. Москва, 1988. С. 31-32.
} 
ку від традиції бронзового віку відокремлює період близько тисячоліття, але і для раннього залізного віку виділення поховань ремісників не властиве. Для скіфського часу, крім ливарної форми із Марицинського могильника, В.А. Іллінська пише про ще одну знахідку подібного роду. Це уламок стулки ливарної форми, в якій відливались вуздечні налобники у вигляді голівки грифона, із кургану, дослідженого C.I. Мазаракі біля с. Аксютинці у Посуллі у 1883 р. ${ }^{18}$ Значення цієї знахідки підсилювалось тим, що і марицинське, й аксютинське поховання схожі за обрядом поховання та наявністю в них античної кераміки першої половини V ст. до н.е. ${ }^{19}$ Але, дивним чином, у звіті C.I. Мазаракі ніде про цю форму не йдеться, є лише інформація про сам налобник.

Ясність на це непорозуміння пролив Б.А. Шрамко. По-перше, він відзначив незвичайність конфігурації форми, яка у кожній наступній публікації набувала нові абриси, але про обломи або деформацію країв ніде нічого не сказано. У документації Київського історичного музею ця форма набула назву «вапнякової», хоча на повірку вона виявилась з гіпсу - матеріалу непридатного для ливарних форм. Посилаючись на приватну розмову зі співробітником Державного Ермітажу А.П. Манцевич про дослідження Б.З. Рабиновича, Б.А. Шрамко пише, що той, працюючи у фондах музеїв, часто робив гіпсові зліпки з речей, виконаних у скіфському звіриному стилі 20 . Тому в колекції Київського історичного музею, як виявляється, зберігався муляж ливарної форми у виконанні Б.З. Рабиновича.

Хто ж був похований у похованні Марицинського могильника? Його поодинокість свідчить про те, що соціальний статус ремісників мало чим відрізнявся від статусу інших общинників. Але ті, хто здійснювали обряд цього поховання, чомусь явно хотіли підкреслити приналежність померлого до бронзоливарного ремесла, вдавшись при цьому до давно забутого анахронізму, - поклали у поховання ливарну форму (або муляж форми?), що повинно було вказати, ймовірно, на незвичайність ситуації. Принаймні навіть поблизу добре досліджених потужних ремісничих центрів скіфського часу поховання із ремісничим інвентарем на сьогодні не відомі. На відсутність таких поховань звернули увагу і при дослідженні стародавніх копалень у Балкано-Карпатській гірничо-металургійній області 21 . Хоча саме біля ремісничих центрів, або гірничих виробок, наявність поховань з аксесуарами металургійного виробництва, або металообробного ремесла, була б цілком логічною. Чи не було покладено у поховання ливарну форму тому, що їі володар помер далеко від домівки, але знаходячись на чужині, він продовжував займатись своїм ремеслом? Тобто тут ми маємо справу знову із мандрівними майстрами, які поховали свого товариша, а можливо старійшину колективу (клану).

Отже, усі сліди обробки кольорових металів на ранніх грецьких поселеннях слід пов'язувати з роботою заїжджих (мандрівних) майстрів - вихідців з різних областей Європи, які торгували виготовленою на місці продукцією, про що свідчить варварський вигляд практично усіх виробів з бронзи, й, у той же час, їхні типологічні відмінності та розбіжності хіміко-металургійних характеристик. Оскільки робота цих майстрів носила тимчасовий, можливо, сезонний характер, або це було

\footnotetext{
18 Ильинская В.А. Скифы днепровского лесостепного Левобережья. Киев, 1968. С. 34.

19 Ильинская В.А. Скифы... С. 76.

20 Шрамко Б.А. К вопросу о бронзолитейном производстве в Скифии // Евразийские древности. Москва, 1990. С. 318-324.

21 Черных Е.Н. Горное дело и металлургия в древнейшей Болгарии. София, 1978. С. 283.
} 
пов'язано, наприклад, із часом активізації торгівлі після прибуття торгівельних кораблів із метрополії, то й майстерні були тимчасові, відкритого типу або переносні, тому й сліди цих майстерень не збереглись.

\section{REFERENS}

Chernykh, E.N. (1976). Drevniaia metalloobrabotka na Yugo-Zapade SSSR [Ancient metalworking in the South-West of the USSR]. Moskva: Nauka [in Russian].

Chernykh, E.N. (1978). Gornoe delo i metallurgiia $v$ drevneishei Bolgarii [The Mining industry and metallurgy in ancient Bulgaria]. Sofiia: Izdatelstvo Bolgarskoi Akademii nauk [in Russian].

Gavriliuk, N.A. \& Otreshko, V.M. (1982). Lepnaia keramika arkhaicheskogo poseleniia Bolshaia Chernomorka 2 [The Stucco ceramics of the archaic settlement Bolshaia Chernomorka 2]. In Drevnosti Stepnoi Skifii (pp. 75-90). Kiev: Naukova dumka [in Russian].

Golubeva, L.A. (1988). Devochki-liteishchitsy [Foundry girls]. In Drevnosti slavian i Rusi (pp.31-34). Moskva: Nauka [in Russian].

Ilinskaia, V.A. (1968). Skify dneprovskogo lesostepnogo Levoberezhia [The Scythians of the forest-steppe Dnieper Left Bank]. Kiev: Naukova dumka [in Russian].

Ilinskaia, V.A. \& Terenozhkin, A.I. (1986). Materialnaia kultura. Zaniatiia i orudiia truda [Material culture. Works and tools]. In Arkheologiia Ukrainskoi SSR (T. 2, pp. 128-134). Kiev: Naukova dumka [in Russian].

Kubyshev, A.I. \& Nechitailo, A.L. (1991) Tsentry metalloobrabatyvaiushchego proizvodstva AzovoChernomorskoi zony (k postanovke problem) [Centers of metalworking manufacturing Azov-Black Sea Region (to the statement of the problem)]. In Katakombnye kultury Severnogo Prichernomoria (pp. 6-21). Kiev, AN Ukrainy [in Russian].

Kryzhitskii, S.D., Buiskikh, S.B., Burakov, A.V. \& Otreshko, V.M. (1989). Selskaia okruga Olvii [Rural district of Olbia]. Kiev: Naukova dumka [in Russian].

Marchenko, K.K. \& Domanskii, Ya.V. (1983) Kompleks veshchestvennykh nakhodok na antichnom poselenii Staraia Bogdanovka 2 [The complex of material finds in the ancient settlement of Staraia Bogdanovka 2]. Arkheologicheskii sbornik Gosudarstvennogo Ermitazha, 24, 56-72 [in Russian].

Olhovskyi, S.Ya. (2011). Skifo-antychna metaloobrobka arkhaichnoho chasu [The Scythian-antique metalworking of archaic times]. Kiev-Moskva: KNT, Universitet D. Pozharskogo [in Ukraine].

Ostroverkhov, A.S. \& Otreshko, V.M. (1986). Novyi obrazets zverinogo stilia naidennyi bliz Olvii [A new sample of animal style found near Olbia]. In Pamiatniki drevnego iskusstva Severo-Zapadnogo Prichernomoria (pp. 61-66). Kiev: Naukova dumka [in Russian].

Ruban, V.V. (1979). Liteinaia forma s poseleniia KozyrkaXV [The mold from the settlement of Kozyrka XV]. Sovetskaia arkheologiia, 3, 249-258 [in Russian].

Shtitelman, F. (1947). Dvi lyvarni formy dlia bronzovykh nakonechnykiv stril iz zbirky Kyivskoho istorychnoho muzeiu [Two foundry molds for bronze arrowheads from the collection of the Kyiv Historical Museum]. Arkheolohiia, I, 161-164 [in Ukrainian].

Shramko, B.A. (1967). Issledovaniia lesostepnoi polosy USSR [The Research of the forest-steppe belt of the Ukrainian SSR]. In Arkheologicheskie otkrytiia 1966 g. (pp. 199-201). Moskva: Nauka [in Russian].

Shramko, B.A. (1976). Novye nakhodki na Bel'skom gorodishche i nekotorye voprosy formirovaniia i semantiki obrazov zverinogo stilia [New findings on the Bel'sk hillfort and some issues of the formation and semantics of animal style images]. In Skifo-sibirskii zverinyi stil v iskusstve narodov Evrazii (pp. 194-209). Moskva: Nauka [in Russian].

Shramko, B.A. (1990). K voprosu o bronzoliteinom proizvodstve v Skifii [On the issue of bronze casting in Scythia]. In Evrazijskie drevnosti (pp. 318-324). Moskva: Nauka [in Russian].

Slavin, L.M. (1953). Osnovnye itogi issledovaniia Olvii za poslednie gody [The main results of the research of Olbia in recent years]. In VI Nauchnaia konferentsiia IA AN USSR (pp. 119-139). Kiev: Izdatelstvo AN USSR [in Russian].

Yatsenko, I.V. (1959). Skifiia VII-V vv. do n.e. [Scythia of the $7^{\text {th }}-5^{\text {th }}$ centuries BC]. In Trudy Gosudarstvennogo istoricheskogo muzeia, 36. Moskva [in Russian]. 


\author{
Serhii Olhovskyi \\ (Kyiv National University of Culture and Arts, Kyiv, Ukraine) \\ e-mail: olgovskiy@online.ua \\ ORCID: https://orcid.org/0000-0002-8677-9312
}

\title{
Barbarian Smelters in Lower Buh Region in Archaic Times
}

The level of bronze casting development in the Northern Black Sea region in the $6^{\text {th }}-5^{\text {th }}$ century BCE is analyzed in the paper. The author concludes that, contrary to the traditional view of the exclusive role of ancient colonies in the history of the local population, non-ferrous metalworking in the Greek colonies was inferior to Scythian in terms of volume and complexity of technological techniques.

Such point of view was formed as a result of a certain lacuna in the study of Scythian sites of settled life, which appeared in the mid-19th century, and was adhered to until the 50s of the $20^{\text {th }}$ century when an extensive study of the Scythian ancient settlements in the forest-steppe zone began. At the site of almost every large ancient settlement, clear traces of local metalworking, significantly exceeding Olbia ones in terms of amount and quality of material, were detected. Stationary foundries with sets of tools, numerous products of barbarian smelters, and semi-finished produced items were found. The quantity of Scythian foundry molds, about which the researchers in the 40 s of the $20^{\text {th }}$ century wrote that only a few items had been known, today numbers a few dozen items, and their collection greatly exaggerates a similar assemblage from Olbia.

Analysis of the remains of metalworking from Olbia and the Lower Buh region as a whole makes it possible to state that at that time in Olbia and in the settlements of its chora, in Berezan and Yahorlyk settlements mostly worked strolling smelters, natives of the barbarian area - the Balkans and Carpathians basin, the forest-steppe zone of Ukraine, the North Caucasus and even the Volga-Urals region and Western Siberia. This is corroborated, first of all, by the nature of the produced items - barbaric adornments and arrowheads of various types, typical of certain areas of the Northern Black Sea region and the East.

Also, the raw material itself raises many questions, and one of the fundamental questions is where the Greek colonists took the metal on the unfamiliar territory. And the analysis of metal produced items showed the presence of metal not only from the Balkans and the Carpathians but also from the Volga-Urals and North Caucasus deposits, which the Greeks in the $6^{\text {th }}$ century BCE hardly knew. We do not mention the mythical route from Olbia to the Volga region and the Urals since it did not exist. Greek merchants were frequent visitors to the Dnipro region Scythian ancient settlements, but they did not get beyond the Dnipro rapids. No Greek item is known in the areas of Ananin culture. On the other hand, Scythian weapons and metal adornments, made in the Scythian animal style, are often found at the sites of ancient settlements and necropolises.

Keywords: non-ferrous metalworking, bronze casting, strolling smelters, foundry molds 